\title{
WATERCRESS AND AMPHIPODS \\ Potential Chemical Defense in a Spring Stream Macrophyte
}

\author{
RAYMOND M. NEWMAN, ${ }^{1-3}$ W. CHARLES KERFOOT ${ }^{2,4}$ and \\ ZAC HANSCOM, III $^{5}$ \\ ${ }^{1}$ Natural Resource Management and Engineering \\ University of Connecticut \\ Storrs, Connecticut 06268 \\ ${ }^{2}$ The University of Michigan Biological Station \\ Pellston, Michigan 49769 \\ ${ }^{4}$ Great Lakes Research Division, and Department of Biology \\ University of Michigan \\ Ann Arbor, Michigan 48109. \\ ${ }^{5}$ Department of Biology \\ San Diego State University \\ San Diego, California 92182
}

(Received February 1, 1989; accepted March 17, 1989)

\begin{abstract}
We investigated the potential role of defensive chemicals in the avoidance of watercress (Nasturtium officinale) by the cooccurring amphipod, Gammarus pseudolimnaeus at two spring brooks: Carp Creek, Michigan and Squabble Brook, Connecticut. We conducted observations and laboratory experiments on the consumption of watercress, the toxicity of damaged (frozen) watercress, and the toxicity of damage-released secondary chemicals. Field-collected yellowed watercress typically lacked the bite and odor characteristic of green watercress and was consumed by $G$. pseudolimnaeus. $G$. pseudolimnaeus strongly preferred yellowed watercress to green watercress despite the higher nitrogen content of the latter ( $2.7 \mathrm{vs} 5.4 \%$ ), and usually consumed five times more yellowed watercress ( $>50 \%$ of yellowed leaf area vs. $<8 \%$ of green leaf area presented). Fresh green watercress contained seven times more phenylethyl glucosinolate than yellowed watercress (8.9 $\mathrm{mg} / \mathrm{g}$ wet vs. $1.2 \mathrm{mg} / \mathrm{g}$ ). Cell-damaged (frozen) watercress was toxic to $G$. pseudolimnaeus (48-hr $\mathrm{LC}_{50} \mathrm{~s}$ : ca. $1 \mathrm{~g}$ wet/liter), and the primary volatile secondary chemicals released by damage were highly toxic. The predominant
\end{abstract}

\footnotetext{
${ }^{3}$ Present address: Fisheries and Wildlife, 1980 Folwell Ave., University of Minnesota, St. Paul, Minnesota 55108.
} 
glucosinolate hydrolysis product, 2-phenylethyl isothiocyanate had 48 -hr $\mathrm{LC}_{50} \mathrm{~s}$ between 0.96 and $3.62 \mathrm{mg} / \mathrm{liter}$, whereas 3-phenylpropionitrile was less toxic, with $48-\mathrm{hr}^{\mathrm{L} C_{50}}$ s between 130 and $211 \mathrm{mg} /$ liter. These results suggest that live watercress is chemically defended against consumption. The glucosinolate-myrosinase system, recognized as the principle deterrent system of terrestrial crucifers, is also possessed by $N$. officinale and may contribute to defense from herbivory by aquatic crustaceans. This system may be just one of many examples of the use of defensive chemicals by stream and lake macrophytes.

Key Words-Nasturtium officinale, Rorippa nasturtium-aquaticum, Gammarus pseudolimnaeus, freshwater, streams, herbivory, chemical defense, glucosinolates, phenylethyl isothiocyanate.

\section{INTRODUCTION}

Invertebrate herbivory on live macroscopic plants is conspicuously rare in freshwater systems (Otto and Svensson, 1981; Wetzel, 1983; for exceptions see Gaevskaya, 1969; and Sheldon 1987). Vascular macrophytes are important as both invertebrate habitats and as substrata for epiphytic periphyton (e.g., Hutchinson, 1975; Gregg and Rose, 1985). When these plants die or senesce, i.e., when tissues rapidly decompose (Webster and Benfield, 1986), they contribute directly to the particulate energy base of aquatic systems, providing energy to detritivores or decomposers (Wetzel, 1983; Mann, 1988).

Despite low herbivory on macrophytes, few have investigated plant-animal interactions from a chemical standpoint, which has resulted in a common opinion that chemical defenses are relatively unimportant in freshwater macrophytes (McClure, 1970; Hutchinson, 1975). Recently, Lamberti and Moore (1984) noted that there is insufficient information available to assess the importance of antiherbivore chemicals in freshwater plants, although Otto and Svensson (1981) and Ostrofsky and Zettler (1986) have argued for a greater role of secondary chemicals in freshwater plant defense. Most recently, Hay and colleagues (see Hay and Fenical, 1988, for a review) have shown that secondary chemicals are very important determinants of seaweed use by marine herbivores. Our study of watercress [Nasturtium officinale R. Br. - synonym: Rorippa nasturtium-aquaticum (L.) Hayek], a common spring-brook macrophyte, and Gammarus pseudolimnaeus Bousfield, a commonly cooccurring amphipod, suggests that this macrophyte is chemically defended from herbivory and that the defensives act in a manner comparable to terrestrial relatives.

Watercress is a crucifer that possesses glucosinolates and myrosinase, which are common to the family (Kjaer, 1976). It was introduced to North America in the 1700s from Europe and is now widely distributed in the United States (Green, 1962) in alkaline springs and spring-fed streams, where it often establishes extensive beds (Howard and Lyon, 1952; Voss, 1985). Because of 
its use as a food for humans, much information is available on watercress aroma and taste-related chemistry. Glucosinolate and myrosinase are stored separately in the plant, but upon tissue damage, glucosinolate hydrolysis is mediated by myrosinase to yield characteristic isothiocyanates and nitriles (Van Etten and Tookey, 1979; Larsen, 1981). In watercress, 2-phenylethyl isothiocyanate and 3-phenylpropionitrile are the predominant hydrolysis products (MacLeod and Islam, 1975; Spence and Tucknott, 1983) and constitute 25-55\% of the volatile compounds. The 2-phenylethyl isothiocyanate is considered the predominant flavor component and imparts the characteristic "hot" taste of watercress (Freeman and Mossadeghi, 1973).

In terrestrial studies, glucosinolates and corresponding isothiocyanates of crucifers are considered classical examples of chemical defense (Feeny, 1976, 1977). These compounds are deleterious to nonadapted herbivores (e.g., Lichtenstein et al., 1964; Blau et al., 1978) and will reduce herbivore damage (Louda and Rodman, 1983; Louda et al., 1987). Moreover, isothiocyanates are released as a response to direct damage of tissues, underscoring the causal relationship with herbivory. Isothiocyanates are especially noxious and can be quite toxic (Lichtenstein et al., 1964; Lowe et al., 1971; Åhman, 1986). However, we know of no research on the ecological implications of the mustard oil system in aquatic plants such as watercress.

Amphipods are also commonly found in alkaline spring streams and often occur among watercress (Howard and Lyon, 1952; Hynes and Harper, 1972; Gregg and Rose, 1985). In particular, Gammarus are generalist consumers in that they eat other animals, terrestrial leaf litter, algae (Marchant and Hynes, 1981; Sutcliffe et al., 1981), and are able to digest cellulose (Bärlocher and Porter, 1986). Gammarus also readily consumes decomposing macrophytes (e.g., Newman et al., 1987), including watercress (Newman, unpublished manuscript).

In this study, we report the results of feeding choice tests with watercress leaves, the concentrations of isothiocyanate yielding glucosinolates in watercress, and the toxicity of frozen watercress and glucosinolate degradation products to Gammarus pseudolimnaeus. We suggest that the lack of aquatic herbivory on North American watercress is in large part due to a chemical defense system. Watercress may represent one of many emergent macrophytes that have carried defensive systems into the aquatic environment.

\section{METHODS AND MATERIALS}

Observations were made in Connecticut (Squabble Brook, East Canaan, Connecticut; $42^{\circ} 1^{\prime} \mathrm{N}, 73^{\circ} 16^{\prime} \mathrm{W}$ ) and Michigan (Carp Creek, $45^{\circ} 33^{\prime} \mathrm{N}, 84^{\circ} 41^{\prime} \mathrm{W}$; T36N, R3W, S4, Cheboygan County, Michigan). Both streams were spring 
fed, and typically maintain temperatures of $7-13^{\circ} \mathrm{C}$. The waters were alkaline with conductivities between 200 and $300 \mu \mathrm{S} / \mathrm{cm}$ and support extensive watercress beds.

In the course of detritivory experiments, we discovered that watercress possesses noxious compounds that are harmful to Gammarus and hypothesized that glucosinolate hydrolysis products (2-phenylethyl isothiocyanate and 3-phenylpropionitrile) were the harmful agents, because senescing yellow leaves have less of the characteristic watercress aftertaste. To evaluate this hypothesis, we performed feeding choice tests with fresh and yellow (senescent) watercress leaves to determine the extent that watercress was palatable to G. pseudolimnaeus.

Feeding Choice Test. To determine if Gammarus would readily consume fresh watercress, we conducted feeding choice tests, comparing yellowed watercress leaves with fresh green leaves. Preliminary field observation had suggested some damage to senescent yellowed leaves. For these experiments, most yellowed leaves were obtained by keeping leaves in the dark at $10^{\circ} \mathrm{C}$ for about one week, but some yellowed leaves were collected from plants in the streams. Eight amphipods (ca. $5 \mathrm{mg}$ dry wt. each) were placed into choice chambers (modified $100 \times 20$-mm Petri dishes, divided into four pie-shaped compartments that were open to one another) with $60 \mathrm{ml}$ filtered stream water. The amphipods were allowed to acclimate to the chambers $\left(10^{\circ} \mathrm{C}\right)$ without food for 12 or $48 \mathrm{hr}$, which resulted in two levels of starvation. Leaf disks (ca. 105 $\mathrm{mm}^{2} ; 25 \mathrm{mg}$ wet) were cut from fresh and yellowed leaves with a cork borer. Disks were randomly assigned to choice chambers, one disk per compartment, in one of four categories: 3 green disks; 2 green +1 yellow disk; 1 green +2 yellow (CT); or 1 green +1 yellow disk (MI); 2 green +2 yellow disks. Disks were held in compartments by pinning the disks with insect pins to silicon knobs in each compartment. The amphipods were allowed to feed for $24 \mathrm{hr}$, the disks were removed, and disk area remaining was computed (by planimeter or digitizer). During each experiment, a set of four green and four yellow disks were placed in chambers without amphipods and served as controls to estimate initial areas. For each choice type there were 6-12 replicates at 12 - and $48-\mathrm{hr}$ starvation periods.

Damaged Tissue Tests. Toxicity tests were conducted with frozen watercress to determine the presence of harmful chemicals. Mustard oils are typically in minute concentrations prior to plant damage. Freezing, however, produces extensive plant damage and, upon thawing, promotes the hydrolysis of glucosinolates to the corresponding isothiocyanates and nitriles.

Fresh watercress leaves were clipped from the plants, washed, blotted dry, and then frozen at ca. $-15^{\circ} \mathrm{C}$. Toxicity tests were conducted in $100 \times 15-\mathrm{mm}$ plastic Petri dishes containing $40 \mathrm{ml}$ of filtered stream water. Ten amphipods (ca. $5 \mathrm{mg}$ dry wt. each) were placed in each Petri dish and acclimated for 24 
$\mathrm{hr}$ in an environmental chamber at ambient stream temperature (ca. $10^{\circ} \mathrm{C}$ ). The frozen leaves were thawed and predetermined wet weights of leaf tissue were randomly placed into each dish, which was then covered. Triplicate dishes of each of five concentrations (a control and four levels of watercress) were used in each toxicity assay. Mortality was observed over time for $48 \mathrm{hr}$. Lethal concentrations $\left(\mathrm{LC}_{50}\right.$ values) and confidence intervals were computed with the trimmed Spearman-Karber method (Hamilton et al., 1977).

Toxicity of Secondary Compounds. Toxicity tests were also conducted with the two secondary compounds known to be prevalent in watercress: 2-phenylethyl isothiocyanate and 3-phenylpropionitrile (Aldrich Chemical Co., Milwaukee, Wisconsin). Experimental conditions were identical to the damaged tissue tests. Because the compounds were volatile oils, serial dilutions were made with absolute ethanol and appropriate concentrations were applied to inert filter disks (Reeve Angel Cellulose disks). Filter disks with the appropriate amount of compound were placed in each Petri disk (concentrations of 0.1-25 mg/liter for 2-phenylethyl isothiocyanate and $25-375 \mathrm{mg} /$ liter for 3-phenylpropionitrile), three replicate dishes per concentration. Filter disks with an amount of ethanol equal to that in the lowest concentration (highest dilution) were placed in the control dishes. The experiments were then conducted and analyzed in the same manner as the frozen watercress experiments.

Chemical Analyses. Watercress was analyzed for carbon, hydrogen, nitrogen, and isothiocyanate-yielding glucosinolates during summer 1988 in Michigan. Fifteen subsamples (2-4 mg, dry) of yellowed and green leaves were dried $\left(65^{\circ} \mathrm{C}\right)$ and analyzed for carbon, hydrogen, and nitrogen with a Perkin-Elmer $24000 \mathrm{CHN}$ Total Elemental Analyzer. The subsamples were taken from leaflet material remaining after disks were cut for the choice experiments and represent the range of material used in the choice tests. A sample of watercress roots as also analyzed.

Glucosinolate content was analyzed for frozen leaves as well as fresh green and yellowed leaves used in the choice experiments. Samples of fresh and yellowed leaves (0.8-2.6 g wet) were obtained from leaf material remaining from different choice tests and immediately boiled for $10 \mathrm{~min}$ in $70 \%$ methanol. Glucosinolate analyses were done (within three months) according to the methods described by Blua (1984) and Blua and Hanscom (1986), except that phenylethyl isothiocyanate was used as the standard for isothiocyanate concentration determination. Results are expressed as milligrams of phenylethyl isothiocyanate-yielding glucosinolate (IYG) per gram (wet) watercress. Concentrations of phenylethyl isothiocyanate from the tissues can be determined by multiplying the IYG concentrations by 0.371 . Frozen watercress was analyzed for phenylethyl isothiocyanate directly, without fixation or the standard myrosinase treatment. Subsamples of thawed, frozen watercress $(0.8-2.6 \mathrm{~g}$ wet) were placed in $40 \mathrm{ml}$ cold water, and $10 \mathrm{ml}$ methylene chloride was then added and the bottles 
were shaken vigorously to extract the released isothiocyanates. The methylene chloride phase was later processed (within three months) and analyzed by GC for isothiocyanate content in the same manner as done for the fresh and yellowed samples. Standard extraction procedures and analysis (e.g., Blua and Hanscom 1986) of the thawed leaf tissue remaining after methylene chloride extraction revealed no detectable glucosinolates. A set of standards prepared on filter disks (similar to the toxicity test disks) was treated in the same way as the frozen watercress samples; analysis showed almost $100 \%$ recovery.

\section{RESULTS}

Watercress Chemistry. Fresh green watercress contained the highest concentrations of carbon, hydrogen, and nitrogen, with total nitrogen $>5 \%$ and $\mathrm{C} / \mathrm{N}$ ratio of 7.27 (Table 1 ). Yellow leaves had significantly lower carbon and nitrogen $(2.7 \%$ ) with a $\mathrm{C} / \mathrm{N}$ ratio of 12.7 . Roots had the lowest nitrogen and the highest $\mathrm{C} / \mathrm{N}$ ratio (16).

Fresh green watercress also had much higher concentrations of phenylethyl glucosinolate $(8.9 \mathrm{mg} / \mathrm{g})$ than yellowed leaves $(1.2 \mathrm{mg} / \mathrm{g} ; P<0.001)$ (Table 2 ). Frozen green watercress yielded phenylethyl isothiocyanate concentrations nearly identical to fresh watercress $(P>0.5)$, which suggests that freezing and thawing resulted in nearly complete hydrolysis of the phenylethyl glucosinolate to isothiocyanate.

Choice Tests. Amphipods readily consumed yellowed leaf disks (typically $40-60 \%$ of the area offered), but rarely consumed more than $10 \%$ of the fresh green disks (Figures 1 and 2). For each choice type (e.g., two fresh and two

Table 1. Carbon, Nitrogen, and Hydrogen Concentrations (\% dry wt) in WATERCRESS LEAVES AND ROOTS

\begin{tabular}{lccc}
\hline & Green leaves & Yellowed leaves & Roots \\
\hline$N^{a}$ & 15 & 15 & 5 \\
Carbon & 37.89 & 30.18 & 37.34 \\
2 SE & 1.04 & 0.72 & 0.64 \\
Hydrogen & 6.04 & 5.45 & 5.85 \\
2 SE & 0.13 & 0.14 & 0.13 \\
Nitrogen & 5.37 & 2.70 & 2.39 \\
2 SE & 0.49 & 0.64 & 0.31 \\
C/N ratio & 7.27 & 12.74 & 15.85 \\
$2 \mathrm{SE}$ & 0.68 & 1.94 & 1.93 \\
\end{tabular}

${ }^{a}$ Number of samples. 
Table 2. Phenylethyl Glucosinolate Concentrations ( $\mathrm{mg} / \mathrm{g}$ wet) Yielded from Fresh Green, Yellowed, and Frozen Green Watercress in Michigan, $1988^{a}$

\begin{tabular}{lccc}
\hline & Green leaves & Yellowed leaves & Frozen green \\
\hline$N$ & 11 & 12 & 6 \\
$\mathrm{mg} / \mathrm{g}$ & 8.85 & 1.24 & 9.55 \\
$2 \mathrm{SE}$ & 2.22 & 0.48 & 1.38 \\
\hline
\end{tabular}

${ }^{a} N=$ number of samples. Phenylethyl isothiocyanate concentrations can be obtained by multiplying by 0.371 .
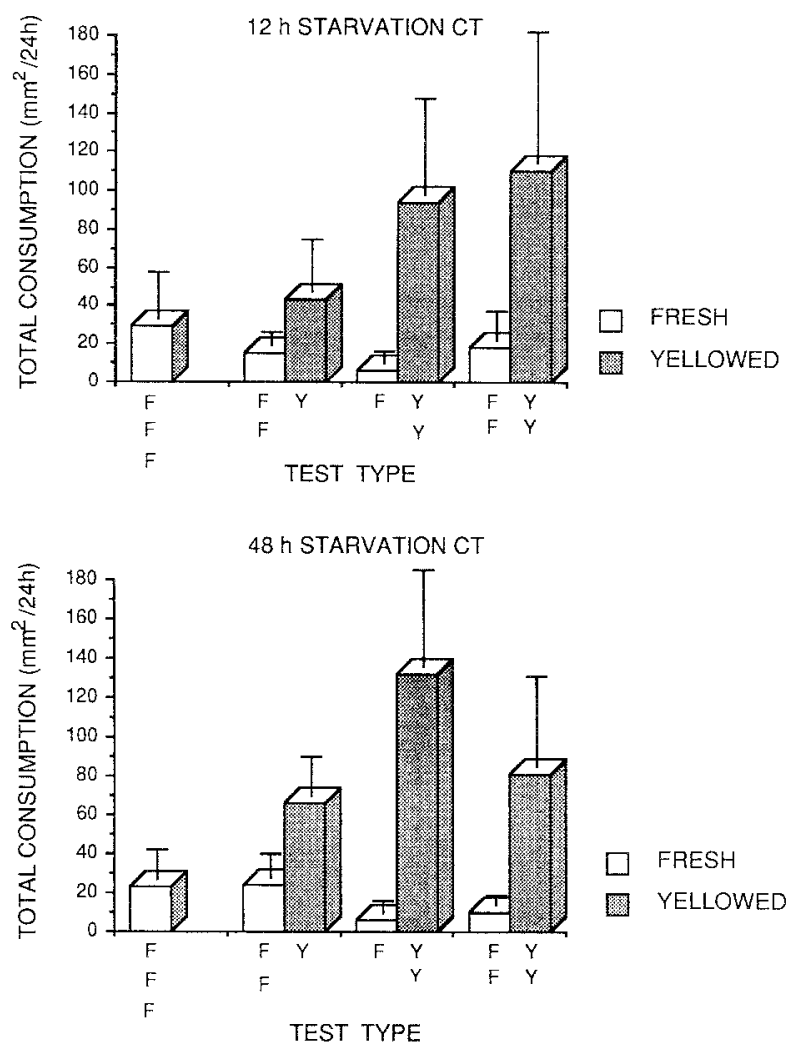

FIG. 1. Consumption (area/24 hr) of fresh green (F) and yellowed (Y) leaf disks by Gammarus pseudolimnaeus in Connecticut, November 1987, after 12- and 48-hr starvation periods. Test type indicates the number of fresh and yellow disks offered. Vertical lines represent +2 SEs. 

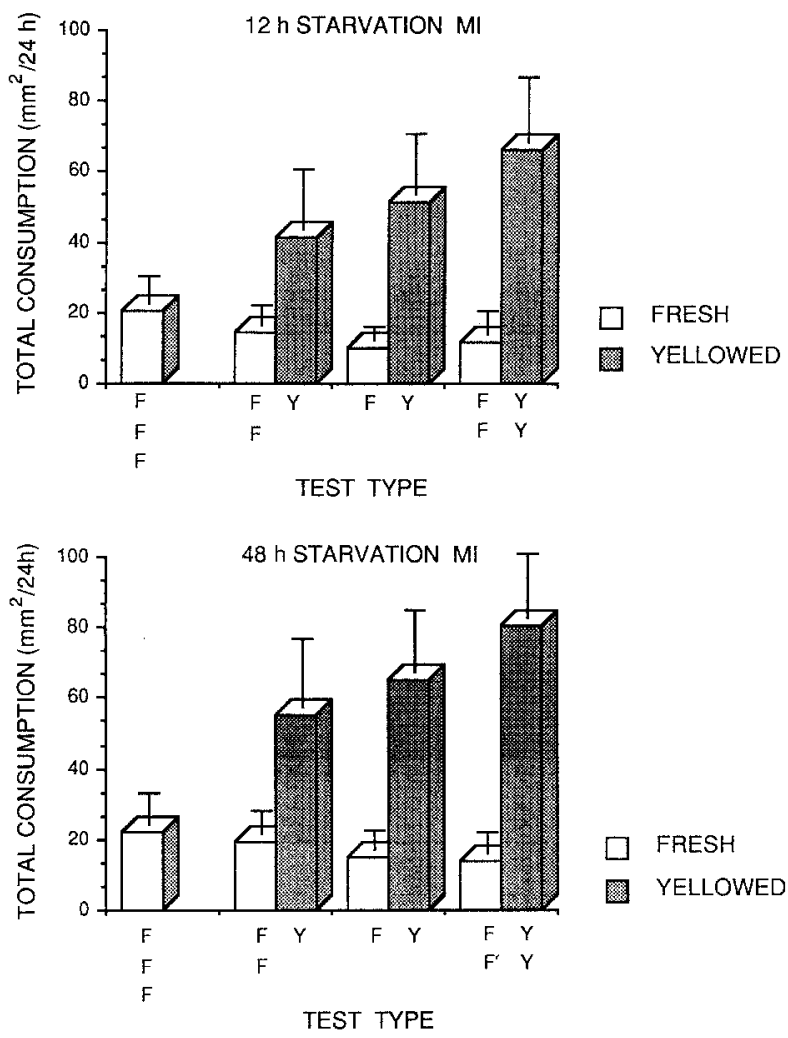

FIG. 2. Consumption (area/24 hr) of fresh green (F) and yellowed (Y) leaf disks by Gammarus pseudolimnaeus in Michigan, July-August 1988, after 12- and 48-hr starvation period. Test type indicates the number of fresh and yellow disks offered. Vertical lines represent +2 SEs.

yellow disks), both total consumption and mean consumption (an average disk) of yellowed disks was significantly higher than that of green disks ( $t$ tests; all $P<0.01$ ). Even when Gammarus was starved for $48 \mathrm{hr}$ and provided only green disks, total consumption was less than half that of yellow disks. Starvation duration (12 or $48 \mathrm{hr}$ ) did not increase the consumption of leaf disks in Connecticut but did increase consumption significantly in Michigan $(P<0.05)$. Consumption of cress (both green and yellow) by amphipods in Michigan and Connecticut was not significantly different $(P>0.05)$.

Damaged Tissue Tests. Frozen watercress was toxic to the amphipods. Amphipod mortality showed typical dose-response curves, with no mortality at the lowest concentrations, partial mortality at intermediate concentrations, and 
TABle 3. TOXICITY OF Frozen WATERCRESS to Gammarus pseudolimnaeus ${ }^{a}$

\begin{tabular}{lcc}
\hline & $\begin{array}{c}48-\mathrm{hr} \mathrm{LC}_{50} \\
(\mathrm{mg} / \mathrm{liter})\end{array}$ & $\begin{array}{c}95 \% \mathrm{CL} \\
(\mathrm{mg} / \mathrm{liter})\end{array}$ \\
\hline Leaves & 475 & $420-540$ \\
Michigan (August 1987) & 1122 & $996-1262$ \\
Connecticut (November 1987) & $928^{b}$ & $871-990$ \\
Michigan (July 1988) & 967 & $863-1084$ \\
Roots & & \\
Michigan (July 1988) & & \\
\hline
\end{tabular}

${ }^{a}$ Forty-eight-hour $\mathrm{LC}_{50}$ values were computed with the trimmed Spearman-Karber method, with four levels (plus controls) per test and three replicates per level. All concentrations are for wet weight.

${ }^{b}$ Combined results of two tests; eight levels plus controls.

complete mortality at the highest concentrations. The $48-\mathrm{hr} \mathrm{LC}_{50}$ values for leaves ranged from 475 to over $1000 \mathrm{mg}$ (wet)/liter (Table 3). Toxicity of roots was similar to leaves. Observations during the tests suggested that most mortality occurred within $24 \mathrm{hr} ; 24-\mathrm{hr} \mathrm{LC}_{50}$ s were $<30 \%$ larger than $48-\mathrm{hr} \mathrm{LC}_{50}$ s. Toxic levels of frozen cress appeared to result in abnormally high rates of gut evacuation, which were not seen at low and control levels. New amphipods introduced into the highest concentrations after the 48-hr experiments were also killed, but the toxic action was reduced.

Toxicity of Secondary Compounds. Previous research demonstrated that 2-phenylethyl isothiocyanate and 3-phenylpropiontrile are predominant glucosinolate hydrolysis products in watercress (MacLeod and Islam, 1975; Cole, 1976; Spence and Tucknott, 1983). Forty-eight-hour LC $_{50}$ values for 2-phenylethyl isothiocyanate were $<4 \mathrm{mg} /$ liter (Table 4). 3-Phenylpropionitrile was not as toxic, giving $\mathrm{LC}_{50}$ values over $100 \mathrm{mg}$ /liter (Table 4 ). Toxic effects were similar to frozen watercress; mortality occurred rapidly and high rates of defecation were noted. The $24-\mathrm{hr} \mathrm{LC}_{50}$ values were not significantly different from 48-hr $\mathrm{LC}_{50}$ values. With 3-phenylpropionitrile, however, amphipods at intermediate concentrations appeared partially paralyzed, but did not die even after $96 \mathrm{hr}$.

\section{DISCUSSION}

Field-collected yellowed watercress typically lacked the bite and odor characteristic of green watercress and was consumed by G. pseudolimnaeus, which strongly preferred yellowed watercress to green watercress, despite the 
TABLE 4. ToXicity of Nasturtium officinale SECONDARY Compounds to Gammarus pseudolimnaeus ${ }^{a}$

\begin{tabular}{lcc}
\hline & $\begin{array}{c}48-\mathrm{hr} \mathrm{LC}_{50} \\
\text { (mg/liter) }\end{array}$ & $\begin{array}{c}95 \% \mathrm{CL} \\
\text { (mg/liter) }\end{array}$ \\
\hline 2-Phenylethyl isothiocyanate & 3.62 & $2.77-4.74$ \\
Michigan (August 1987) & 0.96 & $0.67-1.36$ \\
Connecticut (November 1987) & 1.33 & $0.97-1.82$ \\
Michigan (July, 1988) & 130 & $\mathrm{~N} / \mathrm{A}^{b}$ \\
3-Phenylpropionitrile & $211^{c}$ & $193-230$ \\
Michigan (August 1987) & & \\
Michigan (July 1988) & & \\
\hline
\end{tabular}

${ }^{a}$ Forty-eight-hour $\mathrm{LC}_{50}$ values were computed with the trimmed Spearman-Karber method, with four levels (plus controls) per test and three replicates per level.

${ }^{b}$ Confidence intervals not computable.

${ }^{c}$ Combined results of two tests; eight levels plus controls.

higher nitrogen content of the latter, and usually consumed five times more yellowed watercress. Fresh green watercress, however, had phenylethyl glucosinolate concentrations that were seven times higher than yellowed watercress. Cell-damaged green watercress was toxic to G. pseudolimnaeus. The primary volatile secondary chemicals released by damaged watercress were also highly toxic to G. pseudolimnaeus. These results, although only correlative, suggest that live watercress is chemically defended against consumption and that the glucosinolate-myrosinase system (recognized as the principle deterrent system of terrestrial crucifers) is also active against aquatic crustacean herbivores. Further work is needed to determine if other possible explanations that we did not test for, such as mechanical defense or other chemicals, can be eliminated.

Gammarus and watercress both occur in spring-fed alkaline streams. $G$. pseudolimnaeus is often most abundant in the watercress beds, living among the roots and submerged leaves (Hynes and Harper, 1972; Newman, personal observation). These crustaceans are generalist feeders, consuming algae, other animals, and terrestrial leaf litter (Sutcliffe et al., 1981). Moreover, Gammarus reportedly possesses the ability to digest cellulose (Bärlocher and Porter, 1986). Therefore, G. pseudolimnaeus has the potential to consume watercress, yet little plant damage was observed on green leaves, only on senescing yellow leaves. Others have reported occasional feeding. For example, Minckley (1963) reported that $G$. minus and $G$. bousfieldi contained watercress in their guts, but did not identify whether the material was from living tissue or senescent leaves. 
H.B.N. Hynes (personal communication, University of Waterloo) notes that in England, after commercial watercress beds are cleared for replanting, G. pulex (indigenous to Europe) will consume newly planted watercress cuttings; however, all other food sources are removed during clearing. Sutcliffe et al. (1981) found poor to moderate growth of $G$. pulex on watercress in laboratory trials but also noted high (up to $95 \%$ ) mortality. The only reported aquatic pest of watercress known to us is the trichopteran Limnephilus lunatus, which is indigenous to Europe (Gower, 1967).

As mentioned earlier, in our work, the yellowed cress usually lacked the bite and odor characteristic of fresh watercress and had greatly reduced levels of glucosinolates. Frozen watercress leached in the stream for two days was not toxic to the amphipods and was consumed. Likewise, Feeny and Rosenberry (1982) noted that yellowed senescent leaves of the terrestrial crucifer Dentaria sp. had no detectable glucosinolates. Loss of toxic volatile compounds conicided with marked increase in consumption. G. pseudolimnaeus strongly preferred yellow leaves to green leaves, typically consuming over $50 \%$ of a yellowed leaf disk, but rarely more than $15 \%$ of a green disk. The yellowed disks often lost large areas, whereas $G$. pseudolimnaeus only sampled the edges of green disks, even when no other food was available. The average amount of consumption of individual green leaf disks was similar among test types, further suggesting a sampling of each disk rather than sustained consumption.

Food quality does not appear to explain the lack of consumption of the green leaves. Most aquatic invertebrates, including Gammarus, prefer food with high nitrogen and low $\mathrm{C} / \mathrm{N}$ ratios (Bird and Kaushik, 1981). Fresh leaves had a high nitrogen content (higher than most terrestrial and aquatic plants reported by Otto and Svensson, 1981) and a low $\mathrm{C} / \mathrm{N}$ ratio (yet similar to the ratio of 7.5:1 reported for watercress by Dawson, 1980), which suggest a high food quality. In contrast, yellowed cress had significantly lower nitrogen and higher $\mathrm{C} / \mathrm{N}$ ratios. Therefore, choice seems unrelated to food quality.

In our experiments, cell damage via freezing leached substances toxic to G. pseudolimnaeus. Freezing damaged the plant tissue and resulted in high production of glucosinolate hydrolysis products (phenylethyl isothiocyanate) upon thawing. Freezing and thawing apparently resulted in complete hydrolysis of the glucosinolate. The primary products of glucosinolate hydrolysis in watercress are 2-phenylethyl isothiocyanate and the corresponding nitrile (3-phenylpropionitrile; Freeman and Mossadeghi, 1973; MacLeod and Islam, 1975; Spence and Tucknott, 1983). Cole (1976) determined that, after autolysis, watercress produced $74 \mu \mathrm{g}$ of 2-phenylethyl isothiocyanate per gram of watercress and reported no other isothiocyanates or nitriles. Our results showed much higher levels of phenylethyl isothiocyanate, about $3.3 \mathrm{mg} / \mathrm{g}$. Others have reported additional volatiles, but in all cases, 2-phenylethyl isothiocyanate was the predominant compound (Freeman and Mossadeghi, 1972, 1973; Spence and 
Tucknott, 1983). Moreover, Freeman and Mossadeghi (1972) confirmed that 2-phenylethyl isothiocyanate was the chemical responsible for the characteristic odor and "hot" taste of watercress. By comparing our toxicity results to plant phenylethyl isothiocyanate concentrations, it can be seen that the toxicity of frozen cress corresponds well (within a factor of 3 ) with the toxicity and amount of phenylethyl isothiocyanate that would be released upon thawing (Table 2).

The isothiocyanates have been proposed to be the primary defensive agent in terrestrial crucifers (e.g., Feeny, 1977; Louda and Rodman, 1983). Studies with terrestrial invertebrates, mostly insects, have shown 2-phenylethyl isothiocyanate to be quite toxic (e.g., Lichtenstein et al., 1964; Åhman, 1986); Lowe et al. (1971) reported the toxicity to dipteran larvae (Inopus rubriceps) to be at the level of DDT toxicity (a highly toxic insecticide). Our toxicity tests with 2-phenylethyl isothiocyanate and 3-phenylpropionitrile confirm that both are quite toxic to crustaceans. The $48-\mathrm{hr} \mathrm{LC}_{50}$ for 2-phenylethyl isothiocyanate (ca. $1 \mathrm{mg} /$ liter) is comparable to the level of toxicity of moderately toxic insecticides to G. pseudolimnaeus (Mayer and Ellersieck, 1986). Toxicity, feeding, and chemical analyses suggest that G. pseudolimnaeus food choice may be influenced by the presence of defensive chemicals such as 2-phenylethyl isothiocyanate that are released from watercress upon tissue damage. This would appear to be an aquatic analog to the terrestrial crucifer defense system often cited as a classic example of plant defense. We do not know the toxicity of consumed watercress, however. Neither can we rule out mechanical or other chemical differences that may be correlated with senescence and loss of glucosinolates. Thus, more work is needed to determine more positively if the glucosinolate system is the defensive agent.

The subject of chemical defenses in freshwater systems is largely unexplored. A few incomplete studies suggest that chemical defenses may be highly important. For example, LaLonde et al. (1979) showed that the freshwater alga Cladophora possesses fatty acids toxic to dipteran larvae but did not look at food choice or consumption. Similarly, Ostrofsky and Zettler (1986) showed that many aquatic macrophytes possess significant concentrations of alkaloids, but did not relate chemistry to defense. Finally, Otto and Svensson (1981) suggested that the lack of herbivory on aquatic macrophytes was due to defensive chemicals, but they did not relate chemistry to feeding observations. We believe that chemical defenses may be more important in aquatic plants than previously thought and suggest that watercress is only one example of many chemically defended freshwater plants.

This suggestion has important implications for detritivory. Stream invertebrates are quite adept at using detrital material of both autochthonous and allochthonous origin. Aquatic macrophytes decay quite rapidly compared to terrestrial leaf litter (Bird and Kaushik, 1981; Webster and Benfield, 1986) and can be an important component of aquatic energy budgets (Wetzel, 1983; Car- 
penter and Lodge, 1986). One possible reason that macrophytes are not consumed until senescence or death is that they are chemically defended (Smock and Stoneburner, 1980). Watercress has a very rapid decay rate (Bird and Kaushik, 1981; Webster and Benfield, 1986), which is in large part influenced by abundance of shredders such as G. pseudolimnaeus (Newman, unpublished manuscript). Our results suggest that the reason watercress contributes directly to stream invertebrate energetics only upon senescence and death is that this potentially nutritious food source is chemically defended while alive. The loss of noxious compounds after senescence permits rapid decay and high consumption by stream invertebrates.

Acknowledgments-We thank Drs. Frances Chew, Paul Feeny, and Svata Louda for sharing their insights into crucifer-herbivore interactions; and Drs. K.W. Cummins, H.B.N. Hynes, M.E. Power, and V.H. Resh for their insights on stream plants and invertebrates. Dr. W.A. Ellis permitted access to Squabble Brook. Drs. R.D. Fogel, S.F. Hedtke, D.B. Schroeder, F.A. Streams, J.A. Weber, D.A. White, and W.W. Whitworth lent supplies, equipment, or space to R.M.N. S.P. Hendricks performed the CHN analyses at the University of Michigan Biological Station (UMBS). Drs. D.J. Gerhart, R.G. Wetzel, and an anonymous reviewer made many helpful comments on the manuscript. R.M.N. was supported by the Naturalist Ecologist Training Program (UMBS), funded by the Andrew W. Mellon Foundation, and the Department of Renewable Natural Resources, University of Connecticut. Voucher specimens of $G$. pseudolimnaeus and $N$. officinale were deposited with the University of Connecticut, Museum of Natural History, Storrs, Connecticut. W.C.K. acknowledges support from NSF grant DEB 82-07007 for some of the original inspiration of this work, and the continuing support from John Barko and colleagues at The Waterways Experiment Station, Macrophyte Control Division, U.S. Army Corps of Engineers, Vicksburg, Mississippi. Published as paper No. 16,589 of the Scientific Joumal Series of the Minnesota Agricultural Experiment Station based on research conducted under Project 72 and Scientific Contribution 1273 of the Storrs Agricultural Experiment Station of the University of Connecticut.

\section{REFERENCES}

ĂHMAN, I. 1986. Toxicities of host secondary compounds to eggs of the Brassica specialist Dasineura brassicae. J. Chem. Ecol. 12:1481-1488.

BÄRLOCHER, F., and PORTER, C.W. 1986. Digestive enzymes and feeding strategies of three stream invertebrates. J. North Am. Benthol. Soc. 5:58-66.

BIRD, G.A., and KAUSHIK, N.K. 1981. Coarse particulate organic matter in streams, pp. 41-68, in M.A. Lock and D.D. Williams (eds.). Perspectives in Running Water Ecology. Plenum Press, New York.

Blau, P.A., Feeny, P., Contardo, L., and Robson, D.S. 1978. Allyglucosinolate and herbivorous caterpillars: a contrast in toxicity and tolerance. Science 200:1296-1298.

BLuA, M.J. 1984. Identification and variation of glucocapparin in Isomeris arborea Nutt. MS thesis. San Diego State University, San Diego, California.

BLUA, M.J., and HANSCOM, Z. 1986. Isolation and characterization of glucocapparin in Isomeris arborea Nutt. J. Chem. Ecol, 12:1449-1458.

Carpenter, S.R., and Lodge, D.M. 1986. Effects of submersed macrophytes on ecosystem processes. Aquat. Bot. 24:341-370. 
COLE, R.A. 1976. Isothiocyanates, nitriles, and thiocyanates as products of autolysis of glucosinolates in Cruciferae. Phytochemistry 15:759-762.

Dawson, F.H. 1980. The origin, composition and downstream transport of plant material in a small chalk stream. Freshwater Biol. 10:419-435.

FeEnY, P. 1976. Plant apparency and chemical defense. Recent Adv. Phytochem. 10:1-40.

FEENy, P. 1977. Defensive ecology of the Cruciferae. Ann. Mo. Bot. Garden 64:221-234.

FEENY, P., and RoSENBERRY, L. 1982. Seasonal vatiation in the glucosinolate content of North American Brassica nigra and Dentaria species. Biochem. Syst. Ecol. 10:23-32.

FreEMAN, G.F., and MossadEGHI, N. 1972. Studies on sulfur nitrition and flavor production in watercress [Rorippa nasturtium-aquaticum (L.) Hayek]. J. Hortic. Sci. 47:375-387.

FREEMAN, G.F., and MOSSADEGHI, N. 1973. Studies on relationship between water regime and flavor strength in watercress [Rorippa nasturtium-aquaticium (L.) Hayek], cabbage (Brassica oleracea capitata) and onion (Allium opa). J. Hortic Sci. 48:365-378.

GAEVSKAYA, N.S. 1969. The role of higher aquatic plants in the nutrition of the animals of freshwater basins. Vols. I-III. Translated by D.G.M. Muller, edited by K.H. Mann. National Lending Library of Science and Technology, Yorkshire, England.

Gower, A.M. 1967. A study of Limnephilus lunatus Curtis (Trichoptera: Limnephilidae) with reference to its life cycle in watercress beds. Trans. R. Entomol. Soc. London 119:283-302.

GREEN P.S. 1962. Watercress in the New World. Rhodora 64:32-43.

GREGG, W.W., and ROSE, F.L. 1985. Influences of aquatic macrophytes on invertebrate community structure, guild structure, and microdistribution in streams. Hydrobiologia 128:45-56.

Hamilton, M.A., Russo, R.C. and Thurston, R.V. 1977. Trimmed Spearman-Karber method for estimating median lethal concentrations in toxicity bioassays, Environ. Sci. Tech. 11:714719. (Correction: 1978. Environ. Sci. Tech. 12:417.)

HAY, M.E, and W. FENICAL, 1988. Marine plant-herbivore interactions: The ecology of chemical defense. Annu. Rev. Ecol. Syst. 19:111-145.

Howard, H.W., and LyON, A.G. 1952. Biological flora of the British Isles: Nasturtium R.Br., Nasturtium officinale R.Br. [Rorippa nasturtium-aquaticum (L.) Hayek]. J. Ecol. 40:228245.

Hutchinson, G.E. 1975. A Treatise on Limnology. III. Limnological Botany. Wiley Interscience, New York.

Hynes, H.B.N., and HARPER, F. 1972. The life histories of Gammarus lacustris and G. pseudolimnaeus in southem Ontario. Crustaceana (Supplement) 3:229-341.

KJAER, A. 1976. Glucosinolates in the Cruciferae, pp. 207-219, in J.G. Vaughan, A.J. MacLeod, and B.M.G. Jones (eds.). The Biology and Chemistry of the Cruciferae. Academic Press, New York.

LaLonde, R.T., Morris, D.D., Wong, C.F., Gardner, L.C., Eckert, D.J., King, D.R., and Zimmerman, R.H. 1979. Response of Aedes triseriatus larvae to fatty acids of Cladophora. J. Chem. Ecol. 5:371-381.

LAMBERTI, G.A., and MOORE, J.W. 1984. Aquatic insects as primary consumers, pp. 164-195, in V.H. Resh and D.M. Rosenberg (eds.). The Ecology of Aquatic Insects. Praeger Publishers, New York.

LARSEN, P.O. 1981. Glucosinolates, pp. 501-525, in E.E. Conn (ed.). The Biochemistry of Plants: A Comprehensive Treatise, Vol. 7, Secondary Plant Products. Academic Press, New York.

Lichrenstein, E.P., MORGan, D.G., and MukLler, C.H. 1964. Naturally occurring insecticides in cruciferous crops. J. Agric. Food Chem. 12:158-161.

LOUdA, S.M., and RodMAN, J.E. 1983. Concentration of glucosinolates in relation to habitat and insect herbivory for the native crucifer Cardamine cordifolia. Biochem. Syst. Ecol. 11:199207.

LOUDA, S.M., FARRIS, M.A., and BLUA, M.J. 1987. Variation in methylglucosinolate and insect 
damage to Cleome serrulata (Capparaceae) along a natural soil moisture gradient. J. Chem. Ecol. 13:569-581.

Lowe, M.D., Henzell, R.F., and TAYLOR, H.J. 1971. Insecticidal activity to soldier fly larvae, Inapus rubriceps (Macq.) of isothiocyanates occurring in "choumoellier" (Brassica oleracea c.v.) N.Z. J. Sci. 14:323-326.

MACLEOD, A.J., and IsLAM, R. 1975. Volatile flavour components of watercress. J. Sci. Food Agric. 26:1545-1550.

MANN, K.H. 1988. Production and use of detritus in various freshwater, estuarine, and coastal marine ecosystems. Limnol. Oceanogr. 33:910-930.

MarChant, R., and Hynes, H.B.N. 1981. Field estimates of feeding rates for Gammarus pseudolimnaeus (Crustacea: Amphipoda) in the Credit River, Ontario. Freshwater Biol. 11:2736.

MAYeR, F.L., and ElleRSIECK, M.R. 1986. Manual for acute toxicity: Interpretation and data base for 410 chemicals and 66 species of freshwater organisms. Resource Publication 160. USDI, Fish and Wildlife Service, Washington, D.C.

MCClure, J.W. 1970. Secondary constituents of aquatic angiosperms, pp. 233-268, in J.B. Harborne (ed.). Phytochemical Phylogeny. Academic Press, New York.

Minckley, W.L. 1963. The ecology of a spring stream Doe Run, Meade County, Kentucky. Wildl. Monogr. 11:1-124.

Newman, R.M., Perry, J.A., Tam, E., and Crawford, R.L. 1987. Effects of chronic chlorine exposure on litter processing in outdoor experimental streams. Freshwater Biol. 18:415-428.

Ostrofsky, M.L., and ZetTLER, E.R. 1986. Chemical defenses in aquatic plants. J. Ecol. 74:279287.

Otto, C., and Svensson, B.S. 1981. How do macrophytes growing in or close to water reduce their consumption by aquatic herbivores? Hydrobiologia 78:107-112.

SHELDON, S.P. 1987. The effects of herbivorous snails on submerged macrophyte communities in Minnesota lakes. Ecology 68:1920-1931.

SMOCK, L.A., and STONEBuRner, D.L. 1980. The response of macroinvertebrates to aquatic macrophyte decomposition. Oikos 33:397-403.

SPENCE, R.-M.M., and TUCKNOTT, O.G. 1983. Volatiles from the epicuticular wax of watercress (Rorippa nasturtium-aquaticium). Phytochemistry 22:2521-2523.

Sutcliffe, D.W., Carrick, T.R., and Willoughby, L.G. 1981. Effects of diet, body size, age and temperature on growth rates in the amphipod Gammarus pulex. Freshwater Biol. 11:183214.

VAN EtTen, C.H., and TOOKEY, H.L. 1979. Chemistry and biological effects of glucosinolates, pp. 471-500, in G. A. Rosenthal and D.H. Janzen (eds.). Herbivores: Their Interaction with Secondary Plant Metabolites. Academic Press, New York.

Voss, E.G. 1985. Michigan flora. Part II: Dicots (Saururaceae-Cornaceae). Cranbrook Institute of Science, Bulletin 59, Ann Arbor, Michigan.

WeBSter, J.R, and BENFIELD, E.F. 1986. Vascular plant breakdown in freshwater ecosystems. Annu. Rev. Ecol. Syst. 17:567-594.

Wetzel, R.G. 1983. Limnology, 2nd ed. Saunders College Publishing, Philadelphia, Pennsylvaniø. 